\title{
Primary and secondary bacteremia caused by mdr bacteria in ICU patients
}

\author{
E Pappa*, G Sarris, H Pavlou, M Eforakopoulou \\ From ESICM LIVES 2015 \\ Berlin, Germany. 3-7 October 2015
}

\section{Introduction}

Bacteremia caused by multidrug-resistant bacteria brings about a very serious problem and increases the patients' mortality in ICU.

\section{Objectives}

The aim of this study is to look into the incidence and clinical characteristics of the primary and secondary bacteremia due to multidrug-resistant bacteria in ICU patients.

\section{Methods}

For a 3 months period we have studied all cases of primary and secondary bacteremia occurred in patients hospitalized in ICU of KAT Hospital in Athens. The patients' demographic data, the reason of admission, the day when bacteremia occurred, the cultured microbe and its resistance to antibiotics as well as the duration of patients' hospitalization in ICU have been recorded. The statistical significance was resulted from the t-student and chisquare tests.

\section{Results}

58 cases of bacteremia were recorded in $27 \mathrm{ICU}$ patients. 46 of them (79\%) were primary and $12(21 \%)$ were secondary bacteremia. Multidrug-resistant strains have been developed in $26 \%$ of the primary and in 58\% of the secondary bacteremia $(\mathrm{p}<0.05)$. Klebsiella has been the most frequent germ in secondary bacteremia $(\mathrm{p}<0.0001)$ and is associated with the long term hospitalization in ICU $(\mathrm{p}<0.05)$. Bacteremia caused by multidrug-resistant strains had no correlation with the age and the reason of admission but it was significantly associated with the duration of hospitalization in ICU $(\mathrm{p}<0.01)$.

KAT General Hospital, ICU, Athens, Greece

\section{Conclusions}

Multidrug-resistant bacteria are more often in secondary bacteremia. The length of ICU stay is important risk factor for bacteremia caused by multiresistant strains.

Published: 1 October 2015

\section{References}

1. Renaud B, et al: Outcomes of Primary and Catheter-related Bacteremia.A Cohort and Case-Control Study in Critically III Patients. Am J Respir Crit Care Med 2001, 163:1584-1590.

2. Tabah A, et al: Characteristics and determinants of outcome of hospitalacquired bloodstream infections in intensive care units: the EUROBACT International Cohort Study. Intensive Care Med 2012, 38(12):1930-45.

doi:10.1186/2197-425X-3-S1-A885

Cite this article as: Pappa et al:: Primary and secondary bacteremia caused by mdr bacteria in ICU patients. Intensive Care Medicine Experimental 2015 3(Suppl 1):A885.

\section{SpringerOpen ${ }^{\circ}$}

C 2015 Pappa et al.; This is an Open Access article distributed under the terms of the Creative Commons Attribution License (http:// creativecommons.org/licenses/by/4.0), which permits unrestricted use, distribution, and reproduction in any medium, provided the original work is properly cited.
Submit your manuscript to a SpringerOpen ${ }^{\circ}$ journal and benefit from:

- Convenient online submission

- Rigorous peer review

- Immediate publication on acceptance

- Open access: articles freely available online

- High visibility within the field

- Retaining the copyright to your article

Submit your next manuscript at $>$ springeropen.com 